\title{
Discovery of SARS-CoV-2 strain of P.1 lineage harboring K417T/ E484K / N501Y by whole genome sequencing in the city, Japan
}

Yosuke Hirotsu $^{1 *}$ and Masao Omata ${ }^{2,3}$

${ }^{1}$ Genome Analysis Center, Yamanashi Central Hospital, 1-1-1 Fujimi, Kofu, Yamanashi, Japan

${ }^{2}$ Department of Gastroenterology, Yamanashi Central Hospital, 1-1-1 Fujimi, Kofu, Yamanashi, Japan

${ }^{3}$ The University of Tokyo, 7-3-1 Hongo, Bunkyo-ku, Tokyo, Japan

${ }^{*}$ Corresponding author: Yosuke Hirotsu, Genome Analysis Center, Yamanashi Central Hospital, 1-1-1 Fujimi, Kofu, Yamanashi, Japan

Email: hirotsu-bdyu@ych.pref.yamanashi.jp

Tel: +81-55-253-7111, Fax: +81-55-253-8011

ORCID ID: 0000-0002-8002-834X

Running title: SARS-CoV-2 P.1 lineage identified in Japan 
medRxiv preprint doi: https://doi.org/10.1101/2021.02.24.21251892; this version posted February 26, 2021. The copyright holder for this preprint (which was not certified by peer review) is the author/funder, who has granted medRxiv a license to display the preprint in It is made available under a CC-BY-NC-ND 4.0 International license .

\section{Abstract}

On the February 2020, the very first case was an American female from Diamond Princess cruise ship. Since, we have confirmed 136 patients infected with coronavirus disease 2019 (COVID-19) until February 2021. Here, we conducted the whole genome sequencing analysis of severe acute respiratory syndrome coronavirus 2 (SARS-CoV-2) on samples from 70 of 136 patients (51.5\%). These patients were infected in Diamond Princess cruise ship ( $n=1)$, Africa $(n=2)$, Japan $(n=66)$ and Brazil $(n=1)$. The viral genome sequence of a patient on the Diamond Princess cruise ship in February 2020 was similar to that of original strain found in Wuhan, China (19A clade). Four patients, including two returnees from Africa and two lived in Japan, confirmed at the end of March 2020 had sequences similar to those of lineage with D614G mutation, which was endemic in Europe (20A [n=3] and 20B [n=1] clade). The 64 Japanese patients confirmed from September 2020 to January 2021 had sequences similar to those of the currently prevalent lineage $(20 B[n=58]$ and $20 \mathrm{C}$ clade $[\mathrm{n}=6])$. Subsequent analysis revealed three mutations (K417T/ E484K / N501Y) in the receptor binding domain of the spike protein in a man in his 40s. The sequence was identical to the P.1 lineage (also known as 20J/501Y.V3) reported in Brazil. This is the first report of SARS-CoV-2 P.1 lineage identified in the city, Japan. 
medRxiv preprint doi: https://doi.org/10.1101/2021.02.24.21251892; this version posted February 26, 2021. The copyright holder for this preprint (which was not certified by peer review) is the author/funder, who has granted medRxiv a license to display the preprint in It is made available under a CC-BY-NC-ND 4.0 International license .

\section{Introduction}

Severe acute respiratory syndrome coronavirus 2 (SARS-CoV-2) was first identified in Wuhan province, China, at December 2019. The virus is highly transmissible and its basis reproduction number $\left(R_{0}\right)$ is estimated to range between 2.2 and 3.9 [1]. To date, 107 million individuals have been infected with SARS-CoV-2 and 2.4 million patients have passed away from coronavirus disease 2019 (COVID-19) [2].

SARS-CoV-2 belong to the Coronaviridae family and subdivided into genera $\beta$ coronaviruses, subgenus Sarbecovirus. SARS-CoV-2 has a single-stranded, positive-sense RNA genome with a total of 29.9 kilo base pairs in length. SARS-CoV-2 has the largest genome size among RNA virus and encodes for a 3'-5' exoribonuclease with proofreading function, which result in low mutation rate compared to other RNA virus [3].

It is assumed that most of the mutations occur neutrally and may not influence on virus properties. However, pandemic spread of the virus in naïve populations may affect on the selection of mutations that alter pathogenesis, virulence, and/or transmissibility $[4,5]$. Currently, an emergent D614G mutation in the spike glycoprotein of SARS-CoV-2 is prevalent globally $[6,7]$. Afterward, new emerging lineages with spike protein mutations were discovered in United Kingdom (B.1.1.7 lineage, 20I/501Y.V1, also named VOC 202012/01) [8], South Africa (B.1.351 lineage, 20H/501Y.V2) [9] and Brazil (P.1 lineage, 20J/501Y.V3) $[10,11]$. All of these lineages have N501Y mutation in receptor binding domain (RBD), which directly binds to the angiotensin converting enzyme 2 (ACE2) receptor on host cell [12]. N501Y mutation would contribute to the high transmissibility $[13,14]$. The B.1.351 and P.1 lineages have $\mathrm{K} 417 \mathrm{~N} / \mathrm{T}$ and $\mathrm{E} 484 \mathrm{~K}$ mutations along with N501Y in RBD of spike protein.

In this study, we performed the whole genome sequencing using 70 nasopharyngeal swab samples from COVID-19 patient collected between February 2020 and February 2021. 
medRxiv preprint doi: https://doi.org/10.1101/2021.02.24.21251892; this version posted February 26, 2021. The copyright holder for this preprint (which was not certified by peer review) is the author/funder, who has granted medRxiv a license to display the preprint in It is made available under a CC-BY-NC-ND 4.0 International license .

Of 70 samples, we identified SARS-CoV-2 P.1 lineage in the Kofu city, Japan.

\section{Methods}

\section{Patients and sample collection}

A total of 136 COVID-19 patients were confirmed in our hospital. Of these, we included 70 samples for subsequent genome analysis. For these patients, one was a passenger on a Diamond cruise ship on February 2020, four was confirmed at our district on the end of March 2020, 64 was confirmed on September 2020 to January 2021, and one was on February 2020. These included one American patient infected in Diamond Princess cruise ship, two returnees from Africa, one returnee from Brazil and 66 Japanese, one year past from first confirmed case.

Nasopharyngeal swab samples were collected using cotton swabs and placed in 3 $\mathrm{mL}$ of viral transport media (VTM) purchased from Copan Diagnostics (Murrieta, CA, USA). We used $200 \mu \mathrm{L}$ of the VTM were used for nucleic acid extraction within 2 hours after sample collection.

\section{Viral nucleic acid extraction}

Total nucleic acid was isolated from the samples using the MagMAX Viral/Pathogen Nucleic Acid Isolation Kit (Thermo Fisher Scientific, Waltham, MA, USA) on the KingFisher Duo Prime System (Thermo Fisher Scientific) as we previously described $[15,16]$. Briefly, we added $200 \mu \mathrm{L}$ of VTM, $5 \mu \mathrm{L}$ of proteinase $\mathrm{K}, 265 \mu \mathrm{L}$ of binding solution, $10 \mu \mathrm{L}$ of total nucleic acid-binding beads, $0.5 \mathrm{~mL}$ of wash buffer, and $0.5-1 \mathrm{~mL}$ of $80 \%$ ethanol to each well of a deep-well 96-well plate. The nucleic acids were eluted with $70 \mu \mathrm{L}$ of elution buffer. 
medRxiv preprint doi: https://doi.org/10.1101/2021.02.24.21251892; this version posted February 26, 2021. The copyright holder for this preprint (which was not certified by peer review) is the author/funder, who has granted medRxiv a license to display the preprint in It is made available under a CC-BY-NC-ND 4.0 International license .

\section{Quantitative reverse transcription PCR (RT-qPCR)}

According to the protocol developed by the National Institute of Infectious Diseases (NIID) in Japan [15, 17-19], we performed one-step RT-qPCR to detect SARSCoV-2. This PCR amplifies the nucleocapsid (M) gene of SARS-CoV-2 (NC_045512.2). For the internal positive control, the human ribonuclease P protein subunit p30 (RPP30) gene was used (Integrated DNA Technologies, Coralville, IA, USA) [3]. The RT-qPCR assays were conducted on a StepOnePlus Real-Time PCR System (Thermo Fisher Scientific) with the following cycling conditions: $50^{\circ} \mathrm{C}$ for $5 \mathrm{~min}$ for reverse transcription, $95^{\circ} \mathrm{C}$ for $20 \mathrm{~s}$, and 45 cycles of $95^{\circ} \mathrm{C}$ for $3 \mathrm{~s}$ and $60^{\circ} \mathrm{C}$ for $30 \mathrm{~s}$. The absolute copy number of viral loads was determined using serial diluted DNA control targeting the N gene of SARS-CoV-2 (Integrated DNA Technologies) as previously described [18].

\section{Antigen test}

The sample antigen levels were determined quantitatively with the LUMIPULSE SARS-CoV-2 Ag test (Fujirebio, Inc., Tokyo, Japan) according to the manufacturer's instructions [20-22]. In brief, $700 \mu \mathrm{L}$ of the VTM samples were briefly vortexed, transferred into a sterile tube, and centrifuged at 2,000 $\times g$ for 5 min. Aliquots $(100 \mu \mathrm{L})$ of the supernatant were used for testing on the LUMIPULSE G600II automated system (Fujirebio). For samples with an antigen level $>5,000 \mathrm{pg} / \mathrm{mL}$, the samples were diluted with the kit diluent and retested, and the antigen level was calculated taking the dilution factor into account. Samples with an antigen level $\geq 10 \mathrm{pg} / \mathrm{mL}$ were considered positive, samples with $\geq 1.0 \mathrm{pg} / \mathrm{mL}$ and $<$ $10.0 \mathrm{pg} / \mathrm{mL}$ antigen were labeled inconclusive, while a result of $<1.0 \mathrm{pg} / \mathrm{mL}$ was considered negative as per the manufacturer's guidelines [22]. 
medRxiv preprint doi: https://doi.org/10.1101/2021.02.24.21251892; this version posted February 26, 2021. The copyright holder for this preprint (which was not certified by peer review) is the author/funder, who has granted medRxiv a license to display the preprint in It is made available under a CC-BY-NC-ND 4.0 International license .

\section{Whole genome sequencing}

We amplified the genomic region of SARS-CoV-2 using the lon AmpliSeq SARS-

CoV-2 Research Panel consists of two primer pools covering $99.7 \%$ of the viral genome (Thermo Fisher Scientific). The amplicon size ranges from 125 to 275 base pairs in length. Extracted nucleic acids were subjected to genome sequencing on the lon Torrent Genexus System, which automates the specimen-to-report workflow and yields results in a single day.

\section{Sequencing data analysis}

The data of sequencing reads and quality control were processed on Genexus Software with SARS-CoV-2 plugins. The sequencing reads were mapped and aligned on the reference genome of SARS-CoV-2 strain Wuhan-Hu-1 (Accession no NC_045512) using the torrent mapping alignment program (TMAP). After initial mapping, a variant call was performed using the Torrent Variant Caller. The COVID19AnnotateSnpEff plugin was used for annotation of variants. Assembly was performed with the Iterative Refinement MetaAssembler (IRMA) [23], which produced the FASTA file.

\section{Phylogenic tree analyses and lineage classification}

Phylogenetic tree analysis and classification were conducted using Nextstrain [24] and Global Initiative on Sharing Avian Influenza Data (GISAID) database [25]. The Nextclade beta (https://clades.nextstrain.org/) was used to classify and generate phylogeny of virus strain. 'hCoV-19/Wuhan/WIV04/2019' strain isolated from Wuhan, China used as reference for detecting variants [26]. 
medRxiv preprint doi: https://doi.org/10.1101/2021.02.24.21251892; this version posted February 26, 2021. The copyright holder for this preprint (which was not certified by peer review) is the author/funder, who has granted medRxiv a license to display the preprint in It is made available under a CC-BY-NC-ND 4.0 International license .

FASTA files of SARS-CoV-2 sequence were uploaded on the Nextclade. The nomenclature used by Nextstrain to designate clades are defined by specific signature mutations (https://nextstrain.org/blog/2021-01-06-updated-SARS-CoV-2-clade-naming). The international clade nomenclature system was used according to the Nextstrain.org (https://virological.org/t/updated-nextstain-sars-cov-2-clade-naming-strategy/581). The viral lineages was referred as Phylogenetic Assignment of Named Global Outbreak Lineages (Pangolin; https://cov-lineages.org/index.html) [27].The consensus genome sequence of identified P.1 lineage strain was deposited to the GISAID EpiCoV database with accession (EPI_ISL_978917).

Global sequencing data of P.1 lineage was exported from GISAID EpiCoV database by $14^{\text {th }}$ February, 2021. We searched and found the 121 available datasets. We used these metadata and FASTA files were used for subsequent analysis.

\section{Ethical statement}

The Institutional Review Board of the Clinical Research and Genome Research Committee at Yamanashi Central Hospital approved this study and the use of an opt-out consent method (Approval No. C2019-30). The requirement for written informed consent was waived owing to the observational study and the urgent need to collect data of COVID19. Participation in the study by patients was optional. All methods were performed in accordance with the relevant guidelines and regulations, and with the Helsinki Declaration.

\section{Results}

\section{Landscape of genomic characterization and phylogeny}

To determine the genomic characterization of SARS-CoV-2 identified in the Kofu 
medRxiv preprint doi: https://doi.org/10.1101/2021.02.24.21251892; this version posted February 26, 2021. The copyright holder for this preprint (which was not certified by peer review) is the author/funder, who has granted medRxiv a license to display the preprint in It is made available under a CC-BY-NC-ND 4.0 International license .

city, Japan, we started to whole genome sequencing analysis since $8^{\text {th }}$ January, 2021. A total of the 136 samples obtained from COVID-19 patients who were confirmed in our hospital. Of these, 70 samples were subjected to analysis, which represented $51.5 \%$ of the total confirmed patients by February $15^{\text {th }} 2021$.

The yielded sequence data was subjected to phylogenetic analysis using the Nextclade. As a result, we identified five types of clades including 19A clade $(n=1), 20 A(n=3)$, 20B ( $n=59), 20 \mathrm{C}(\mathrm{n}=6)$ and 20J/501Y.V3 (n=1) (Figure 1).

The SARS-CoV-2 from a patient on Diamond cruise ship was classified into 19A clade (Figure 2), and four patients confirmed on the end of March 2020 were classified into $20 A(n=3)$ and 20B $(n=1)$. From September 2020 to January 2021, SARS-CoV-2 from 64 patients were classified into 20B clade $(n=58)$ and $20 \mathrm{C}(n=6)$ (Figure 2$)$. Newly confirmed patient was classified as 20J/501Y.V3 (P.1 lineage).

\section{Identify a patient infected with SARS-CoV-2 of 20J/501Y.V3 (P.1 lineage)}

A man in his 40s, who had a history of staying in Brazil, attended our hospital in early February with symptoms of fever at $38.9^{\circ} \mathrm{C}$. RT-qPCR judged positive with high viral load $\left(7.1 \log _{10} / \mu \mathrm{L}\right)$ and low Ct value (Ct: 15). The antigen level was also high at 183,426 $\mathrm{pg} / \mathrm{mL}$. The patient was confirmed to be negative for SARS-CoV-2 by airport quarantine when he returned to Japan four days earlier. His symptom was mild and he was admitted to another hospital.

Sequencing analysis revealed that the SARS-CoV-2 of 20J/501Y.V3 (P.1 lineage) had 37 mutations including 22 missense, 10 synonymous, 3 intergenic, one frameshift and one in-frameshift mutation. In spike protein, we observed 12 missense mutations (L18F, T20N, P26S, D138Y, R190S, K417T, E484K, N501Y, D614G, H655Y, T1027I and V1176F). 
medRxiv preprint doi: https://doi.org/10.1101/2021.02.24.21251892; this version posted February 26, 2021. The copyright holder for this preprint (which was not certified by peer review) is the author/funder, who has granted medRxiv a license to display the preprint in It is made available under a CC-BY-NC-ND 4.0 International license .

These mutations were perfectly matched with the mutations in P.1 lineage previously discovered in Brazil [10] (Figure 3). In RBD of spike protein, three mutations (K417T, E484K and N501Y) were identified. These results suggested we identified the emerging strain related to 20J/501Y.V3 (P.1 lineage) in Japan.

\section{Global genomic surveillance of 20J/501Y.V3 (P.1 lineage)}

To examine the global data of SARS-CoV-2 of 20J/501Y.V3 (P.1 lineage), we referred the sequence data deposited in GISAID [25, 28]. By February $14^{\text {th }} 2021$, a total of 121 sequence data was available, and 119 were derived from patient and 2 were viral strains isolated from TMPRSS2-expressing Vero E6 cell line [29].

The SARS-CoV-2 of 20J/501Y.V3 (P.1 lineage) was first discovered in the sample collected December $4^{\text {th }}, 2020$ Manaus, Amazonas state in Brazil (Figure 4A). Afterward, the strain of 20J/501Y.V3 (P.1 lineage) have been continuously identified over the time (Figure $4 A)$.

Almost of 20J/501Y.V3 (P.1 lineage) have 33-40 mutations compared with original strain reported from Wuhan, China [26], and our identified strain had 37 mutations (Figure 4B). Of 119 patients, $82(68.9 \%)$ were identified in Brazil, 5 (4.2\%) in Japan, $20(16.8 \%)$ in Europe, $3(2.5 \%)$ in USA (Table 1), suggesting P.1 lineage began to spread in the world.

\section{Discussion}

We started to the genomic surveillance to monitor the SARS-CoV-2 variants from $8^{\text {th }}$ January, 2021. In this study, we confirmed that five clades have emerged over the time. The consecutive analysis identified SARS-CoV-2 of 20J/501Y.V3 (P.1 lineage) in a patient and detected mutations were identical to those of original P.1 lineage discovered in Brazil 
medRxiv preprint doi: https://doi.org/10.1101/2021.02.24.21251892; this version posted February 26, 2021. The copyright holder for this preprint (which was not certified by peer review) is the author/funder, who has granted medRxiv a license to display the preprint in It is made available under a CC-BY-NC-ND 4.0 International license .

[10]. This is the first report on the 20J/501Y.V3 (P.1 lineage) in the city, Japan.

On January 6, 2021, the NIID detected a new emerging strain (P.1 lineage) of SARS-CoV-2 at airport quarantine in four travelers who arrived from Brazil on $2^{\text {nd }}$ January 2021 [30-32] (Table 1). Subsequently, almost of P.1 lineage discovered in Manaus in Brazil and gradually spread worldwide $[10,11]$. This lineage has several mutations in spike protein and some of these mutations are shared with as 20I/501Y.V1 (B.1.1.7 lineage) in Unites Kingdom and 501Y.V2 (B.1.351 lineage) in South Africa.

In particular, mutations in the RBD of spike protein are noteworthy [33, 34]. N501Y mutation increases the overall binding affinity between RBD and human ACE2 receptor [35, 36]. Recently, escape mutations from neutralizing antibody recognition were identified by SARS-CoV-2 spike protein-expression vesicular stomatitis virus (VSV) and yeast $[37,38]$. The K417N/T, E484K and N501Y mutation reduced the neutralizing activity of convalescent and mRNA vaccine-elicited serum [39-43].

The SARS-CoV-2 variant is not always related to threat to human health because the virus acquires genomic diversity during the course of its life cycle [44]. However, some of these mutations would be associated to attenuate the neutralizing activity of antibody. During the ongoing evolution of SARS-CoV-2, the new emerging lineage is likely to be circulating in the human population. Thus, genomic surveillance is important for public health to monitor the emerging lineage, evaluate vaccine efficacy and virus transmissibility.

\section{Acknowledgments}

This study was supported by a Grant-in-Aid for the Genome Research Project from Yamanashi Prefecture (to M.O. and Y.H.), the Japan Society for the Promotion of Science (JSPS) KAKENHI Early-Career Scientists JP18K16292 (to Y.H.), a Grant-in-Aid for Scientific 
medRxiv preprint doi: $h$ ttps://doi.org/10.1101/2021.02.24.21251892; this version posted February 26, 2021. The copyright holder for this preprint (which was not certified by peer review) is the author/funder, who has granted medRxiv a license to display the preprint in It is made available under a CC-BY-NC-ND 4.0 International license .

Research (B) $20 \mathrm{H} 03668$ (to Y.H.), a Research Grant for Young Scholars (to Y.H.), the YASUDA Medical Foundation (to Y.H.), the Uehara Memorial Foundation (to Y.H.), and Medical Research Grants from the Takeda Science Foundation (to Y.H.). We thank Hitoshi Mochizuki for applying for the ethics committee. We also thank Masato Kondo, Ryota Tanaka and Kazuo Sakai (Thermo Fisher Scientific) for technical help and all of the medical and ancillary hospital staff and the patients for consenting to participate.

\section{Competing Interests Statement.}

The authors declared no conflict of interest 


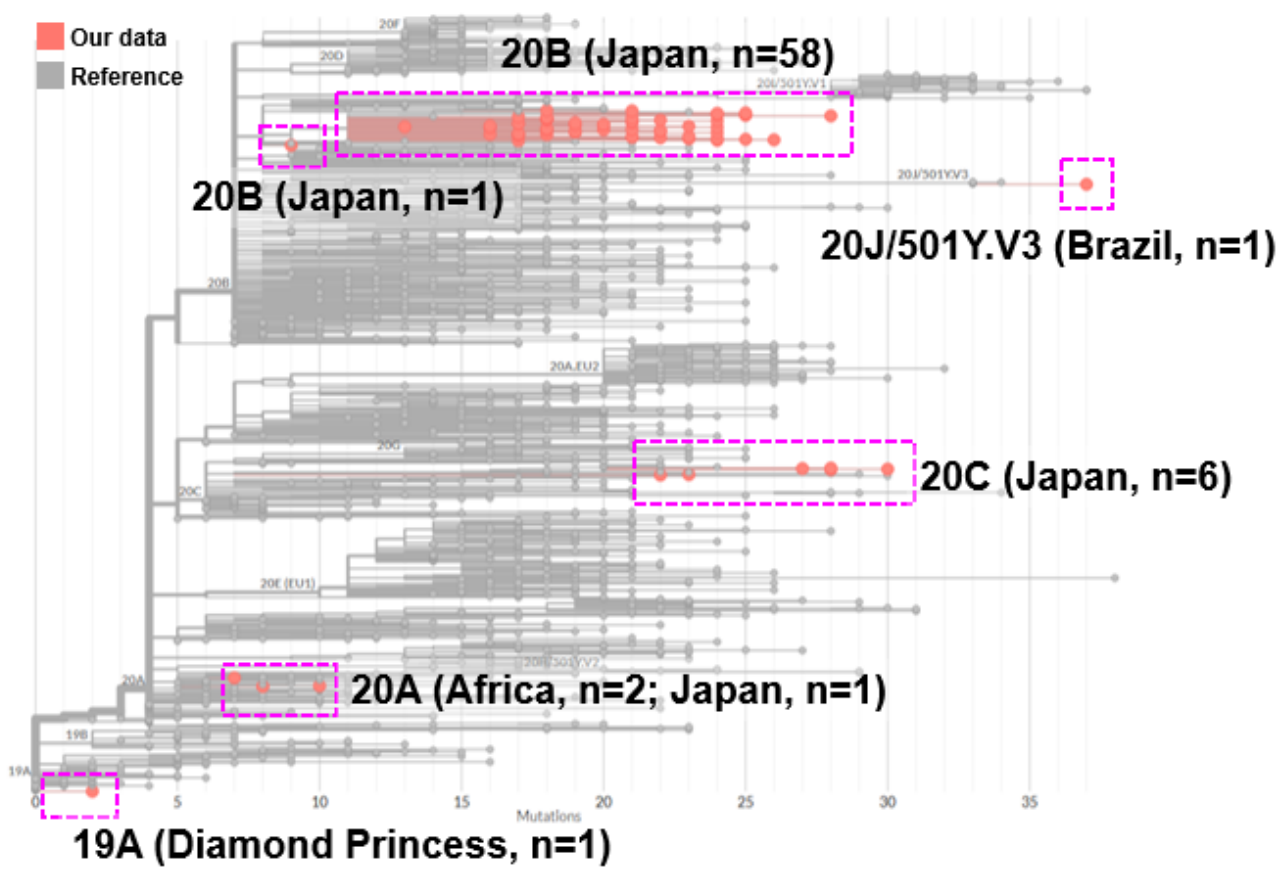

Figure 1. Phylogenetic tree analysis of SARS-CoV-2.

Sequencing data was uploaded to the Nextclade (https://clades.nextstrain.org/) and visualized onto the location of phylogeny. The pink dotted line shows the sequencing data obtained in this analysis. 
medRxiv preprint doi: $h$ ttps://doi.org/10.1101/2021.02.24.21251892; this version posted February 26, 2021. The copyright holder for this preprint (which was not certified by peer review) is the author/funder, who has granted medRxiv a license to display the preprint in It is made available under a CC-BY-NC-ND 4.0 International license .

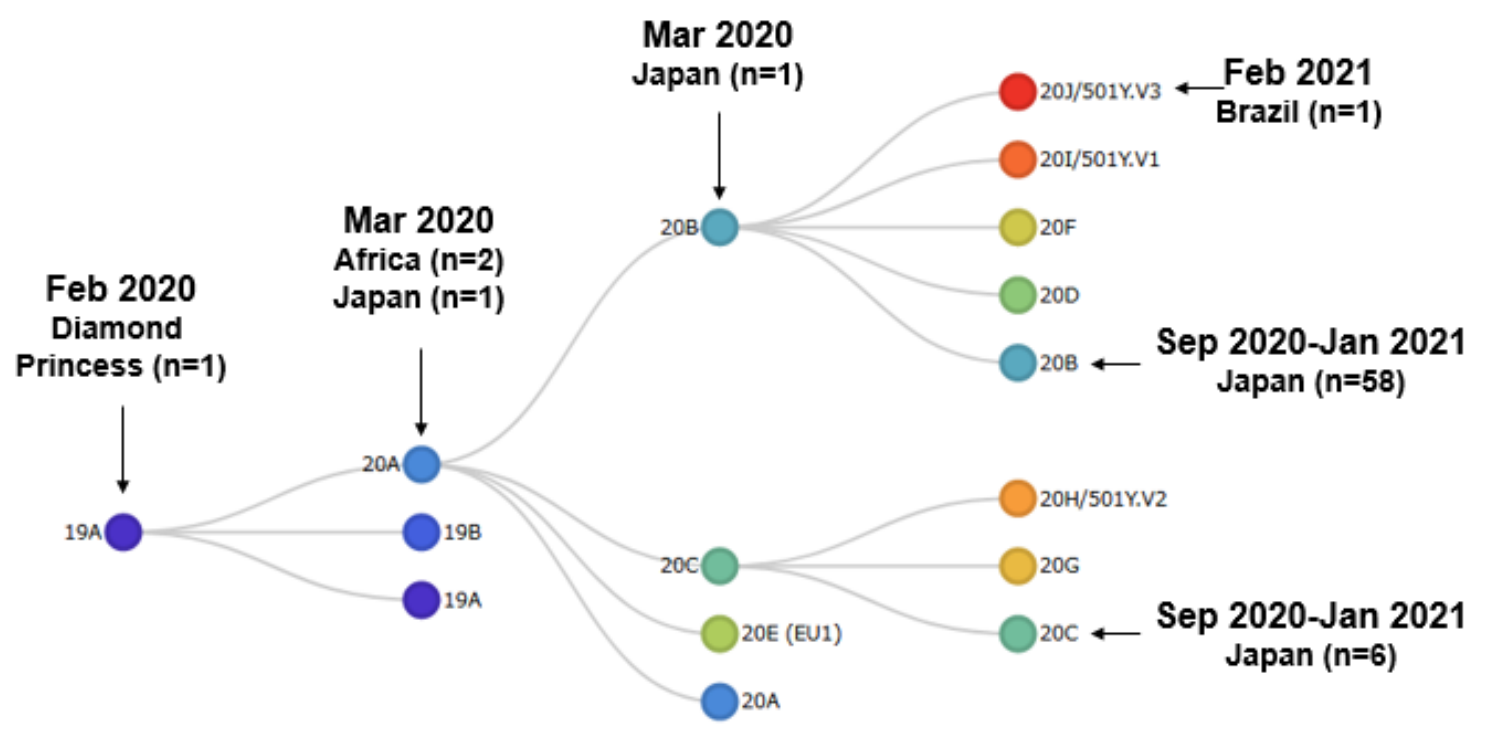

Figure 2.

The relationship between the SARS-CoV-2 clade and timeline.

The schematic tree shows of the Nextstrain clade in website. The arrows indicate the clade into which the 70 patients identified in this analysis were classified. 


\begin{tabular}{|c|c|c|c|c|}
\hline \multirow[b]{2}{*}{$\begin{array}{l}\text { United } \\
\text { Kingdom }\end{array}$} & \multirow[b]{2}{*}{$\begin{array}{l}\text { South } \\
\text { Africa }\end{array}$} & \multirow[b]{2}{*}{ Brazil } & \multicolumn{2}{|c|}{ Japan } \\
\hline & & & $\begin{array}{l}\text { Returnee } \\
\text { from Brazil } \\
\text { Feb, } 2021\end{array}$ & $\begin{array}{c}\text { Two Returnees } \\
\text { from Africa } \\
\text { Mar, } 2020\end{array}$ \\
\hline $\begin{array}{c}69-70 \text { del } \\
145 \text { del } \\
\text { N501Y } \\
\text { A570D } \\
\text { D614G } \\
\text { P681H } \\
\text { T716I } \\
\text { S982A } \\
\text { D1118H } \\
\text { 2011501Y.V1 } \\
\end{array}$ & 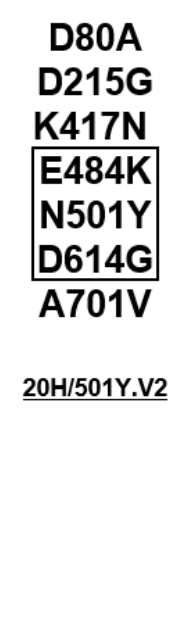 & \begin{tabular}{|c|} 
L18F \\
T20N \\
P26S \\
D138Y \\
R190S \\
K417T \\
E484K \\
N501Y \\
D614G \\
H655Y \\
T1027I \\
V1176F \\
20J501Y.V3 \\
(P.1 lineage) \\
\end{tabular} & $\begin{array}{l}\text { L18F } \\
\text { T20N } \\
\text { P26S } \\
\text { D138Y } \\
\text { R190S } \\
\text { K417T } \\
\text { E484K } \\
\text { N501Y } \\
\text { D614G } \\
\text { H655Y } \\
\text { T1027I } \\
\text { V1176F }\end{array}$ & $\begin{array}{l}\text { ND } \\
\text { ND } \\
\text { ND } \\
\text { ND } \\
\text { ND } \\
\text { ND } \\
\text { ND } \\
\text { ND } \\
\text { D614G } \\
\text { ND } \\
\text { ND } \\
\text { ND }\end{array}$ \\
\hline
\end{tabular}

Figure 3. Mutations in SARS-CoV-2 spike protein

The left side of the dotted line shows the amino acid changes identified in the emerging strains reported in the United Kingdom, South Africa, and Brazil. The right of the dotted line shows the results of the current analysis: the patient who returned from Brazil on February, 2021 had the same mutation as 20J/501Y.V3 (P.1 lineage); the two patients who returned from Africa on March, 2020 had only D614G mutation in spike protein. The highlighted areas surrounded by lines indicate mutations in the receptor binding domain. ND, not detected. 
(A)

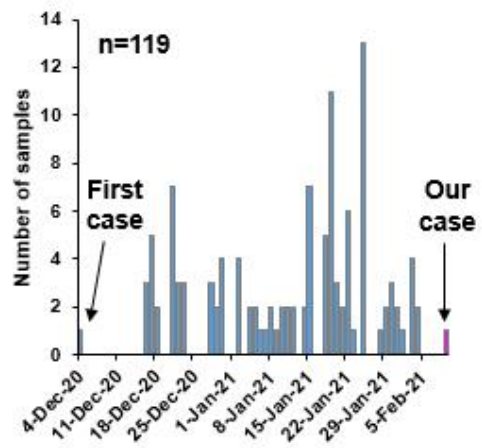

(B)

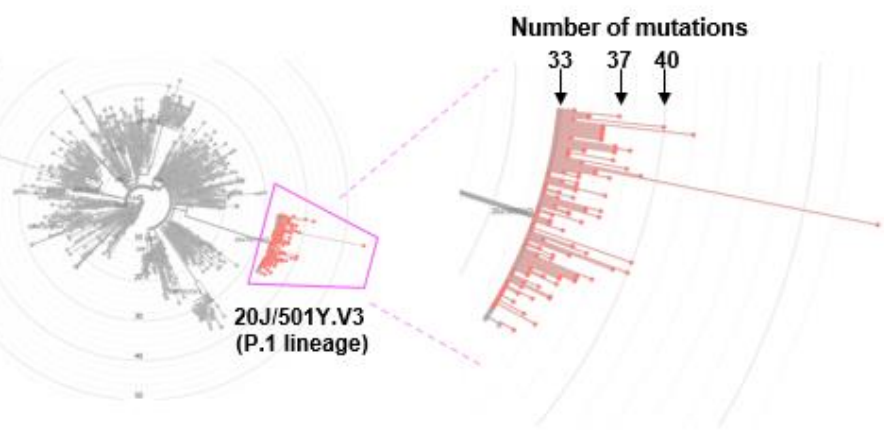

Figure 4. Global data of 20J/501Y.V3 (P.1 lineage) deposited in GASAID.

(A) The number of samples of 20J/501Y.V3 (P.1 lineage) strain deposited in GISAID by February $14^{\text {th }}$ 2021. The first case was identified in December $4^{\text {th }}, 2020$. (B) A total of 119 sequencing data were analyzed on Nextclade. The radial phylogenetic tree shows the location of 20J/501Y.V3 (P.1 lineage) (left diagram). The magnified version of image shows the P.1 lineage surrounded by pink lines (right diagram). The total number of mutation was denoted when the SARS-CoV-2 strain Wuhan, China used as a reference. 
medRxiv preprint doi: https://doi.org/10.1101/2021.02.24.21251892; this version posted February 26, 2021. The copyright holder for this preprint (which was not certified by peer review) is the author/funder, who has granted medRxiv a license to display the preprint in It is made available under a CC-BY-NC-ND 4.0 International license .

Table 1. The prevalence of SARS-CoV-2 of 20J/501Y.V3 (P.1 lineage) in the world

\begin{tabular}{|c|c|c|}
\hline Location & Country & $\begin{array}{l}\text { Number of confirmed } \\
\text { cases }(n=119)\end{array}$ \\
\hline \multirow[t]{2}{*}{ Asia } & Japan & $5^{\star}$ \\
\hline & South Korea & 1 \\
\hline \multirow[t]{3}{*}{ South America } & Brazil & 82 \\
\hline & Colombia & 7 \\
\hline & Peru & 1 \\
\hline \multirow[t]{6}{*}{ Europe } & Switzerland & 9 \\
\hline & France & 4 \\
\hline & Italy & 3 \\
\hline & Netherlands & 2 \\
\hline & Belgium & 1 \\
\hline & Faroe Islands & 1 \\
\hline North America & USA & 3 \\
\hline
\end{tabular}

* Four were identified at airport quarantine and one was identified in this study. 
medRxiv preprint doi: https://doi.org/10.1101/2021.02.24.21251892; this version posted February 26, 2021. The copyright holder for this preprint (which was not certified by peer review) is the author/funder, who has granted medRxiv a license to display the preprint in It is made available under a CC-BY-NC-ND 4.0 International license .

\section{Reference}

1. Lv M, Luo X, Estill J, Liu Y, Ren M, Wang J, Wang Q, Zhao S, Wang X, Yang S et al: Coronavirus disease (COVID-19): a scoping review. Eurosurveillance 2020, 25(15):2000125.

2. World Health Organization: Coronavirus Disease (COVID-19) Situation Reports. https://wwwwhoint/emergencies/diseases/novel-coronavirus-2019/situation-reports.

3. Ogando NS, Ferron F, Decroly E, Canard B, Posthuma CC, Snijder EJ: The Curious Case of the Nidovirus Exoribonuclease: Its Role in RNA Synthesis and Replication Fidelity. Frontiers in Microbiology 2019, 10(1813).

4. Hou YJ, Chiba S, Halfmann P, Ehre C, Kuroda M, Dinnon KH, Leist SR, Schäfer A, Nakajima N, Takahashi $\mathrm{K}$ et al: SARS-CoV-2 D614G variant exhibits efficient replication ex vivo and transmission in vivo. Science 2020, 370(6523):1464-1468.

5. Graham RL, Becker MM, Eckerle LD, Bolles M, Denison MR, Baric RS: A live, impairedfidelity coronavirus vaccine protects in an aged, immunocompromised mouse model of lethal disease. Nat Med 2012, 18(12):1820-1826.

6. Korber B, Fischer WM, Gnanakaran S, Yoon H, Theiler J, Abfalterer W, Hengartner N, Giorgi EE, Bhattacharya T, Foley B et al: Tracking Changes in SARS-CoV-2 Spike: Evidence that D614G Increases Infectivity of the COVID-19 Virus. Cell 2020.

7. Yurkovetskiy L, Wang X, Pascal KE, Tomkins-Tinch C, Nyalile TP, Wang Y, Baum A, Diehl WE, Dauphin A, Carbone C et al: Structural and Functional Analysis of the D614G SARS-CoV-2 Spike Protein Variant. Cell 2020, 183(3):739-751.e738.

8. European Centre for Disease Prevention and Control: Rapid increase of a SARS-CoV2 variant with multiple spike protein mutations observed in the United Kingdom. 2020:1-13. 
medRxiv preprint doi: https://doi.org/10.1101/2021.02.24.21251892; this version posted February 26, 2021. The copyright holder for this preprint (which was not certified by peer review) is the author/funder, who has granted medRxiv a license to display the preprint in It is made available under a CC-BY-NC-ND 4.0 International license .

9. Tegally H, Wilkinson E, Giovanetti M, Iranzadeh A, Fonseca V, Giandhari J, Doolabh D, Pillay S, San EJ, Msomi $\mathrm{N}$ et al: Emergence and rapid spread of a new severe acute respiratory syndrome-related coronavirus 2 (SARS-CoV-2) lineage with multiple spike mutations in South Africa. medRxiv 2020:2020.2012.2021.20248640.

10. Nuno R. Faria, Ingra Morales. Claro, Darlan. Candido, Lucas A. Moyses Franco, Pamela S. Andrade, Thais M. Coletti, Camila A. M. Silva, Flavia C. Sales, Erika R. Manuli, Renato S. Aguiar et al: Genomic characterisation of an emergent SARS-CoV-2 lineage in Manaus: preliminary findings. virologicalorg 2020(20-012021):https://virological.org/t/genomic-characterisation-of-an-emergent-sars-cov-2lineage-in-manaus-preliminary-findings/586.

11. Felipe. Naveca, Valdinete. Nascimento, Victor. Souza, André. Corado, Fernanda. Nascimento, George. Silva, Ágatha. Costa, Débora. Duarte, Karina. Pessoa, Luciana. Gonçalves et al: Phylogenetic relationship of SARS-CoV-2 sequences from Amazonas with emerging Brazilian variants harboring mutations E484K and N501Y in the Spike protein. https://virologicalorg/t/phylogenetic-relationship-of-sars-cov-2sequences-from-amazonas-with-emerging-brazilian-variants-harboring-mutationse484k-and-n501y-in-the-spike-protein/585 2021.

12. Zhao Y, Zhao Z, Wang Y, Zhou Y, Ma Y, Zuo W: Single-Cell RNA Expression Profiling of ACE2, the Receptor of SARS-CoV-2. American Journal of Respiratory and Critical Care Medicine 2020, 202(5):756-759.

13. Davies NG, Abbott S, Barnard RC, Jarvis Cl, Kucharski AJ, Munday J, Pearson CAB, Russell TW, Tully DC, Washburne AD et al: Estimated transmissibility and severity of novel SARS-CoV-2 Variant of Concern 202012/01 in England. medRxiv 2021:2020.2012.2024.20248822. 
medRxiv preprint doi: https://doi.org/10.1101/2021.02.24.21251892; this version posted February 26, 2021. The copyright holder for this preprint (which was not certified by peer review) is the author/funder, who has granted medRxiv a license to display the preprint in It is made available under a CC-BY-NC-ND 4.0 International license .

14. Leung K, Shum MH, Leung GM, Lam TT, Wu JT: Early transmissibility assessment of the N501Y mutant strains of SARS-CoV-2 in the United Kingdom, October to November 2020. Eurosurveillance 2021, 26(1):2002106.

15. Hirotsu Y, Maejima M, Shibusawa M, Nagakubo Y, Hosaka K, Amemiya K, Sueki H, Hayakawa M, Mochizuki H, Tsutsui T et al: Pooling RT-qPCR testing for SARS-CoV-2 in 1000 individuals of healthy and infection-suspected patients. Sci Rep 2020, 10(1):18899.

16. Hirotsu Y, Maejima M, Nakajima M, Mochizuki H, Omata M: Environmental cleaning is effective for the eradication of severe acute respiratory syndrome coronavirus 2 (SARS-CoV-2) in contaminated hospital rooms: A patient from the Diamond Princess cruise ship. Infect Control Hosp Epidemiol 2020, 41(9):1105-1106.

17. Shirato K, Nao N, Katano H, Takayama I, Saito S, Kato F, Katoh H, Sakata M, Nakatsu Y, Mori $Y$ et al: Development of Genetic Diagnostic Methods for Novel Coronavirus 2019 (nCoV-2019) in Japan. Jpn J Infect Dis 2020, 73(4):304-307

18. Hirotsu $\mathrm{Y}$, Mochizuki $H$, Omata M: Double-quencher probes improve detection sensitivity toward Severe Acute Respiratory Syndrome Coronavirus 2 (SARS-CoV2) in a reverse-transcription polymerase chain reaction (RT-PCR) assay $J$ Virol Methods 2020, 284:113926.

19. Omata M, Hirotsu Y, Sugiura H, Maejima M, Nagakubo Y, Amemiya K, Hayakawa M, Tsutsui T, Kakizaki $\mathrm{Y}$, Mochizuki $\mathrm{H}$ et al: The dynamic change of antibody index against Covid-19 is a powerful diagnostic tool for the early phase of the infection and salvage PCR assay errors. Journal of Microbiology, Immunology and Infection 2021.

20. Hirotsu Y, Maejima M, Shibusawa M, Nagakubo Y, Hosaka K, Amemiya K, Sueki H, Hayakawa M, Mochizuki H, Tsutsui T et al: Comparison of Automated SARS-CoV-2 
medRxiv preprint doi: https://doi.org/10.1101/2021.02.24.21251892; this version posted February 26, 2021. The copyright holder for this preprint (which was not certified by peer review) is the author/funder, who has granted medRxiv a license to display the preprint in It is made available under a CC-BY-NC-ND 4.0 International license .

Antigen Test for COVID-19 Infection with Quantitative RT-PCR using 313 Nasopharyngeal Swabs Including from 7 Serially Followed Patients. International Journal of Infectious Diseases 2020.

21. Hirotsu Y, Maejima M, Shibusawa M, Amemiya K, Nagakubo Y, Hosaka K, Sueki H, Hayakawa M, Mochizuki $\mathrm{H}$, Tsutsui T et al: Analysis of a persistent viral shedding patient infected with SARS-CoV-2 by RT-qPCR, FilmArray Respiratory Panel v2.1, and antigen detection. J Infect Chemother 2020.

22. Hirotsu Y, Maejima M, Shibusawa M, Amemiya K, Nagakubo Y, Hosaka K, Sueki H, Hayakawa M, Mochizuki H, Tsutsui $T$ et al: Prospective Study of 1,308 Nasopharyngeal Swabs from 1,033 Patients using the LUMIPULSE SARS-CoV-2 Antigen Test: Comparison with RT-qPCR. International Journal of Infectious Diseases 2021.

23. Shepard SS, Meno S, Bahl J, Wilson MM, Barnes J, Neuhaus E: Viral deep sequencing needs an adaptive approach: IRMA, the iterative refinement meta-assembler. $B M C$ Genomics 2016, 17:708.

24. Hadfield J, Megill C, Bell SM, Huddleston J, Potter B, Callender C, Sagulenko P, Bedford T, Neher RA: Nextstrain: real-time tracking of pathogen evolution. Bioinformatics 2018, 34(23):4121-4123.

25. Shu Y, McCauley J: GISAID: Global initiative on sharing all influenza data - from vision to reality. Euro Surveill 2017, 22(13).

26. Zhou P, Yang X-L, Wang X-G, Hu B, Zhang L, Zhang W, Si H-R, Zhu Y, Li B, Huang C-L et al: A pneumonia outbreak associated with a new coronavirus of probable bat origin. Nature 2020, 579(7798):270-273.

27. Rambaut A, Holmes EC, O'Toole A, Hill V, McCrone JT, Ruis C, du Plessis L, Pybus OG: 
medRxiv preprint doi: https://doi.org/10.1101/2021.02.24.21251892; this version posted February 26, 2021. The copyright holder for this preprint (which was not certified by peer review) is the author/funder, who has granted medRxiv a license to display the preprint in It is made available under a CC-BY-NC-ND 4.0 International license .

A dynamic nomenclature proposal for SARS-CoV-2 lineages to assist genomic epidemiology. Nat Microbiol 2020, 5(11):1403-1407.

28. Elbe S, Buckland-Merrett G: Data, disease and diplomacy: GISAID's innovative contribution to global health. Glob Chall 2017, 1(1):33-46.

29. Matsuyama S, Nao N, Shirato K, Kawase M, Saito S, Takayama I, Nagata N, Sekizuka T, Katoh $\mathrm{H}$, Kato $\mathrm{F}$ et al: Enhanced isolation of SARS-CoV-2 by TMPRSS2-expressing cells. Proceedings of the National Academy of Sciences 2020, 117(13):7001-7003.

30. Sekizuka T, Itokawa K, Yatsu K, Tanaka R, Hashino M, Kawano-Sugaya T, Ohnishi M, Wakita T, Kuroda M, Quarantine C-GSNiJA: COVID-19 genome surveillance at international airport quarantine stations in Japan. Journal of Travel Medicine 2020.

31. National Institute of Infectious Diseases: Brief report: New Variant Strain of SARSCoV-2 Identified in Travelers from Brazil. https://wwwniidgoip/niid/en/2019-ncove/10108-covid19-33-enhtm/ 2021.

32. Sekizuka T, Itokawa K, Hashino M, Kawano-Sugaya T, Tanaka R, Yatsu K, Ohnishi A, Goto K, Tsukagoshi H, Ehara H et al: A Genome Epidemiological Study of SARS-CoV2 Introduction into Japan. mSphere 2020, 5(6):e00786-00720.

33. World Health Organization: SARS-CoV-2 Variants. 2020, https://www.who.int/csr/don/31-december-2020-sars-cov2-variants/en/.

34. Centers for Disease Control and Prevention (CDC): Emerging SARS-CoV-2 Variants. https://wwwcdcgov/coronavirus/2019-ncov/more/science-and-research/scientific-briefemerging-variantshtml 2021.

35. Luan B, Wang H, Huynh T: Molecular Mechanism of the N501Y Mutation for Enhanced Binding between SARS-CoV-2's Spike Protein and Human ACE2 Receptor. bioRxiv 2021:2021.2001.2004.425316. 
medRxiv preprint doi: https://doi.org/10.1101/2021.02.24.21251892; this version posted February 26, 2021. The copyright holder for this preprint (which was not certified by peer review) is the author/funder, who has granted medRxiv a license to display the preprint in It is made available under a CC-BY-NC-ND 4.0 International license .

36. Nelson G, Buzko O, Spilman P, Niazi K, Rabizadeh S, Soon-Shiong P: Molecular dynamic simulation reveals E484K mutation enhances spike RBD-ACE2 affinity and the combination of E484K, K417N and N501Y mutations (501Y.V2 variant) induces conformational change greater than N501Y mutant alone, potentially resulting in an escape mutant. bioRxiv 2021:2021.2001.2013.426558.

37. Weisblum Y, Schmidt F, Zhang F, DaSilva J, Poston D, Lorenzi JCC, Muecksch F, Rutkowska M, Hoffmann $\mathrm{H}-\mathrm{H}$, Michailidis $\mathrm{E}$ et al: Escape from neutralizing antibodies by SARS-CoV-2 spike protein variants. eLife 2020, 9:e61312.

38. Greaney AJ, Starr TN, Gilchuk P, Zost SJ, Binshtein E, Loes AN, Hilton SK, Huddleston J, Eguia R, Crawford KHD et al: Complete Mapping of Mutations to the SARS-CoV-2 Spike Receptor-Binding Domain that Escape Antibody Recognition. Cell Host \& Microbe 2021, 29(1):44-57.e49.

39. Jangra S, Ye C, Rathnasinghe R, Stadlbauer D, Krammer F, Simon V, Martinez-Sobrido L, García-Sastre A, Schotsaert M: The E484K mutation in the SARS-CoV-2 spike protein reduces but does not abolish neutralizing activity of human convalescent and post-vaccination sera. medRxiv 2021:2021.2001.2026.21250543.

40. Wang Z, Schmidt F, Weisblum Y, Muecksch F, Barnes CO, Finkin S, Schaefer-Babajew D, Cipolla M, Gaebler C, Lieberman JA et al: mRNA vaccine-elicited antibodies to SARS-CoV-2 and circulating variants. Nature 2021.

41. Xie X, Liu Y, Liu J, Zhang X, Zou J, Fontes-Garfias CR, Xia H, Swanson KA, Cutler M, Cooper D et al: Neutralization of SARS-CoV-2 spike 69/70 deletion, E484K and N501Y variants by BNT162b2 vaccine-elicited sera. Nat Med 2021.

42. Wu K, Werner AP, Moliva JI, Koch M, Choi A, Stewart-Jones GBE, Bennett H, BoyogluBarnum S, Shi W, Graham BS et al: mRNA-1273 vaccine induces neutralizing 
medRxiv preprint doi: https://doi.org/10.1101/2021.02.24.21251892; this version posted February 26, 2021. The copyright holder for this preprint (which was not certified by peer review) is the author/funder, who has granted medRxiv a license to display the preprint in It is made available under a CC-BY-NC-ND 4.0 International license.

antibodies against spike mutants from global SARS-CoV-2 variants. bioRxiv 2021:2021.2001.2025.427948.

43. Collier DA, De Marco A, Ferreira IATM, Meng B, Datir R, Walls AC, Kemp S SA, Bassi J, Pinto D, Fregni CS et al: SARS-CoV-2 B.1.1.7 escape from mRNA vaccine-elicited neutralizing antibodies. medRxiv 2021:2021.2001.2019.21249840.

44. van Dorp L, Richard D, Tan CCS, Shaw LP, Acman M, Balloux F: No evidence for increased transmissibility from recurrent mutations in SARS-CoV-2. Nature Communications 2020, 11(1):5986. 